Original Article

\title{
Association of blood heavy metal levels with osteocalcin abnormality and incidence of osteoporosis in Saudi subjects
}

\author{
Associação de anormalidades de osteocalcina nos níveis de metais pesados no sangue \\ e incidência de osteoporose em indivíduos sauditas
}

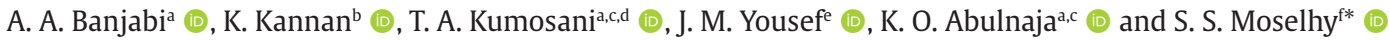 \\ aKing Abdulaziz University - KAU, Faculty of Science, Biochemistry Department, Jeddah, Saudi Arabia \\ bDepartment of Environmental Medicine, New York, University School of Medicine, NY10016, USA. \\ 'King Abdulaziz University - KAU, King Fahd Medical Research Center, Experimental Biochemistry Unit, Jeddah, Saudi Arabia \\ ${ }^{d}$ King Abdulaziz University - KAU, Production of Bio-Products for Industrial Applications Research Group, Jeddah, Saudi Arabia \\ eUniversity of Jeddah, College of Science, Department of Biochemistry, Jeddah, Saudi Arabia \\ ${ }_{\mathrm{f}}^{\mathrm{f}}$ in Shams University, Faculty of Science, Biochemistry Department, Cairo, Egypt
}

\begin{abstract}
Serum toxic metals have been implicated in development of many diseases. This study investigated the association between blood levels of lead and cadmium with abnormal bone mineral density (BMD) and incidence of osteoporosis. Sixty Saudi male adults age matching were assigned into two groups: A healthy control group $(n=30)$ and osteoporosis patients diagnosed according to T-score $(n=30)$. Serum calcium, vitamin $D$, osteocalcin, lead, cadmium were measured. Osteoporotic group showed a highly significant elevation of blood lead and cadmium levels compared to the control group $(\mathrm{p}<0.001)$. BMD was negatively correlated with serum osteocalcin level compared with control. There was a significant negative correlation between the cadmium and lead levels $(\mathrm{r}=-0.465$ and $\mathrm{p}$-value $=0.01)$ and calcium $(\mathrm{p}<0.004)$. Our findings suggested that high cadmium and lead were negative correlated to BMD and increased the risk factor for osteoporosis.
\end{abstract}

Keywords: osteoporosis, bone mineral density, ICP-MS.

\begin{abstract}
Resumo
Os metais tóxicos do soro têm sido implicados no desenvolvimento de muitas doenças. Este estudo investigou a associação entre os níveis sanguíneos de chumbo e cádmio com densidade mineral óssea anormal (DMO) e incidência de osteoporose. Sessenta adultos sauditas do sexo masculino com idades iguais foram divididos em dois grupos: um grupo de controle saudável $(\mathrm{n}=30)$ e pacientes com osteoporose diagnosticados de acordo com o T-score $(\mathrm{n}=30)$. Cálcio sérico, vitamina D, osteocalcina, chumbo, cádmio foram medidos. O grupo osteoporótico apresentou elevação altamente significativa dos níveis de chumbo e cádmio no sangue em comparação ao grupo controle $(\mathrm{p}<0,001)$. A DMO foi negativamente correlacionada com o nível de osteocalcina sérica em comparação com o controle. Houve correlação negativa significativa entre os níveis de cádmio e chumbo $(r=-0,465$ ep =0,01) e cálcio ( $\mathrm{p}<0,004)$. Nossos achados sugeriram que cádmio e chumbo elevados foram correlacionados negativamente à DMO e aumentaram o fator de risco para osteoporose.
\end{abstract}

Palavras-chave: osteoporose, densidade mineral óssea, ICP-MS.

\section{Introduction}

Environmental pollution causes a significant global problem for human health. Over the years, our environment has been filled with pollutants. Consequently, people are frequently exposed to different kinds of environmental contaminants which are linked to deleterious effects on public health worldwide. Among toxic metals, cadmium $(\mathrm{Cd})$ and lead $(\mathrm{Pb})$ are considered as chemical pollutants that require close monitoring (Mol, 2011). They are widely distributed in the environment (Madeddu et al.,
2011), and contaminating the air, water, food sources and soil. Furthermore, they are also present in cigarette smoke. In addition to their harmful effect on the central nervous system, these minerals are carcinogenic, mutagenic and embryotoxic (Arguelles-Velazquez et al., 2013). The sources of exposure to Pb include cosmetics, cookware (Ragab et al., 2014), printing presses, wrapping paper, ceramics, constructing materials, textiles and even toothpaste. In fact, the main sources of $\mathrm{Pb}$ are water, paint,

*e-mail: moselhy6@hotmail.com

Received: February 17, 2021 - Accepted: May 19, 2021 
gasoline, food, soil and dust (Bosch et al., 2016). Regarding $\mathrm{Cd}$, it is found in high concentrations in industrial areas and used in electroplating and galvanizing, as a cathode material for nickel-cadmium batteries, plastics and paints (Bosch et al., 2016). In the general population, food is the major source of $\mathrm{Cd}$. It is also found in tobacco smoke and water (Lavado-Garcia et al., 2017). Cd and $\mathrm{Pb}$ are easily transported across the cell membrane in the organism and accumulated in tissues as well (Macholz, 1978). The half-life of $\mathrm{Cd}$ in soft tissues is estimated to be between 5 and 30 years and about 30 days for $\mathrm{Pb}$. $\mathrm{Pb}$ mainly accumulates in the bones which comprise approximately $90 \%$ of the total amount of body Papanikolaou et al. (2005). On the other hand, Cd accumulates in the kidneys; as a result kidneys have been considered to be a critical target of $\mathrm{Cd}$ toxicity (Klaassen, 2003).

High output from industrial sewage and organic compounds are mainly responsible for environmental pollution. There is an inverse relationship, and increased significantly in downriver polluted areas (Schulz and Martins-Junior, 2001). It was reported that, high dietary cadmium levels increased risk of osteopenia or osteoporosis. In addition, lead exposure may increased risk of osteopenia or osteoporosis (Jalili et al., 2020).

Osteocalcin is calcium binding protein synthesized by osteocyte and osteoblasts and a sensitive biomarker for bone formation due to its role in calcification. Blood levels of osteocalcin are generally related to the rate of bone formation (Ishak et al., 2015).

Osteoporosis, literally "porous bone", is a bone disorder that weakens bones, making them more likely to break. It affects millions of people worldwide, predominantly postmenopausal women while Saudi Arabia is among the countries with highest incidence of osteoporotic fractures. It is a multi-factorial bone disorder and involves the interaction between genes, endocrine function, nutritional and environmental factors (Gartell et al., 1986). Dermience et al. (2015) identified the toxic effects of $\mathrm{Pb}$ and Cd on bone metabolism (Castelli et al., 2005) and higher fracture risk has also been reported from toxic exposure to Cd (Higazy et al., 2010; Castelli et al., 2005). In spite of the fact that these metals are naturally-occurring in our environment and the exposure to them is unavoidable, their osteo-toxic effects have not been extensively investigated in Saudi Arabia. Therefore, the rational of current study is to investigate the association of toxic metals ( $\mathrm{Cd}$ and $\mathrm{Pb}$ ) with risk of osteoporotic bones in Saudi subjects.

\section{Materials and Methods}

\subsection{Subjects}

Samples of the present study were collected from King Fahd Hospital, Jeddah, located in the Western province of Saudi Arabia from March 2017 to January 2018. The research protocol was approved by the National Committee (approval no. A00406). Sixty Saudi subjects were included in this study, age and sex-matched. They were equally divided into two groups, 30 osteoproteic patients according to T-score, whereas the other group was comprised of
30 healthy participants from the general population with no reported symptoms of osteoporosis (control), following bone mineral density (BMD) measurements using dual energy X-ray absorptiometry (DEXA). Informed verbal consent was obtained from every subject after informing the purpose of the study. Body mass index was calculated as BMI $\left(\mathrm{kg} / \mathrm{m}^{2}\right)$. All of the participants underwent physical examination before enrollment in the study. The exclusion criteria included pregnancy, lactating females, the presence of organ dysfunction and terminal illness. BMD of all individuals was measured by DEXA scan (Jeddah, Saudi Arabia). Subjects were assigned to one of the study groups according to their T-score: a normal group (T-score $\geq-1$ ) and osteoporosis group (T-score $\leq-2.5$ ).

From each subject, $5 \mathrm{~mL}$ of whole blood was drawn into heparin coated tubes. Then, blood samples were immediately refrigerated and transported in cold storage to the laboratory and kept at $-40{ }^{\circ} \mathrm{C}$ until they were used.

\subsection{Determination of serum osteocalcin}

Serum osteocalcin was determined by ELISA kit purchased from BIOMEDICA, England with sensitivity of $0.35 \mathrm{ng} / \mathrm{mL}$.

\subsection{Determination of serum calcium and vitamin $D$}

Serum calcium was determined by calorimetric kit while Vitamin D by ELISA technique using kits from Biomedica, England.

\subsection{Microwave digestion of the samples}

Each investigated blood sample $(1 \mathrm{~mL})$ was transferred into a Teflon container, and then $5 \mathrm{~mL}$ of $\mathrm{HNO}_{3}$ was added and left overnight. Next day, $0.5 \mathrm{~mL}$ of $\mathrm{H}_{2} \mathrm{O}_{2}$ were added. Then, they were placed in a microwave and heated to digest.

\subsection{Heavy metals measurement using inductive coupled plasma-mass spectrometry (ICP-MS)}

This method was described previously, but with some modifications.

\subsection{Statistical analysis}

Data analyses were performed using SPSS- version 20 software. Medians were used to describe the studied samples. Univariate and multivariate regression analyses were also applied. Finally, Pearson's correlation was applied to find correlation between heavy metals and osteoporosis. P-Values $<0.05$ was considered as statistically significant.

\section{Results}

Data in Table 1 showed that, the median age of the osteoporosis patients was 65 (55.75-76) years, which cross matched the median age of the control group 62.5 (41.75-60.5). Non significant changes in the level of calcium were noted between the two groups ( $\mathrm{p}=0.882$ ). Contrarily, vitamin D showed higher significant levels in control than that in osteoproteic group, $\mathrm{p}=0.009$. The concentration level ranges and averages of $\mathrm{Cd}$ and 
Table 1. The BMI, serum calcium and vitamin D and osteocalcin in studied groups (mean \pm SD).

\begin{tabular}{|c|c|c|c|c|}
\hline \multicolumn{2}{|c|}{ Variables (Units) } & Osteoporosis & Control & p-value \\
\hline \multicolumn{2}{|c|}{ Age (years) } & 65 & 62.5 & 0.871 \\
\hline \multirow[t]{4}{*}{ BMI $\left(\mathrm{kg} / \mathrm{m}^{2}\right)$} & Underweight & $10 \%$ & $0.0 \%$ & - \\
\hline & Normal & $13.3 \%$ & $36.7 \%$ & \\
\hline & Overweight & $46.7 \%$ & $43.3 \%$ & \\
\hline & Obese & $30 \%$ & $20 \%$ & \\
\hline \multicolumn{2}{|c|}{ Calcium (mg/dL) } & $9.15 \pm 0.91$ & $9.25 \pm 0.88$ & 0.882 \\
\hline \multicolumn{2}{|c|}{ Vitamin D (ng/mL) } & $15.3 \pm 1.1$ & $24.45 \pm 1.3$ & 0.009 \\
\hline \multicolumn{2}{|c|}{ Osteocalcin (ng/mL) } & $17.12 \pm 1.61$ & $10.12 \pm 0.91$ & \\
\hline
\end{tabular}

BMI: Body mass index.

$\mathrm{Pb}$ in the osteoporosis group were 0.02-0.09 (0.03) and 0.1-0.9 (0.41), respectively. Osteocalcin level was significantly increased in osteoporosis group compared with control group. Pearson correlation showed a negative correlation with BMD. On the other hand, the concentration level ranges and averages of $\mathrm{Cd}$ and $\mathrm{Pb}$ in the control group were 0.01-0.03 (0.02) and 0.1-0.4 (0.26), respectively. Table 2 demonstrated that the blood levels of both $\mathrm{Cd}$ and $\mathrm{Pb}$ in the osteoporosis group were higher than those in the control ( $\mathrm{p}<0.001$ and 0.001 ), respectively.

Uni-variant logistic regression test verified that age and vitamin D have significant effects on osteoporosis, p-value $=0.001$ and 0.004 and ORs $=1.083$ and 0.924 , respectively. Conversely, BMI and calcium did not show a significant effect (Table 3 ). With regard to multivariant logistic regression, the model was significant ( $\mathrm{p}$-value $<0.0005$ and Nagelkerke R Square $=0.504$ ) and revealed that age and vitamin $\mathrm{D}$ have significant effects on the incidence of osteoporosis, $\mathrm{p}=0.002$ and 0.005 , while ORs $=1.11$ and 0.914 , respectively. In contrast, BMI and calcium failed to show any significant effect (Table 4). Pearson's correlation analysis was also performed and proved a positive correlation between $\mathrm{Cd}$ and $\mathrm{Pb}, \mathrm{r}=0.505$ and p-value $=0.004$, in the osteoporosis samples. On the other hand, the control samples recorded a negative correlation $(\mathrm{r}=-0.465$ and $\mathrm{p}$-value $=0.01)$ between $\mathrm{Cd}$ and $\mathrm{Pb}$ (Table 5$)$.

The Dual energy X-ray absorptiometry (DEXA) refrences range for BMD indicated by the value of T score, if T-score was -1.0 or more this is normal healthy bone density. While if T-score ( -1.0 to -2.5$)$, it indicated osteopenia and if T-score lower than -2.5 it indicated osteoporosis. Our results indicated that obese women showed T score $=-2.31$ while overweight women showed $\mathrm{T}$ score of -1.76 compared with control group $\mathrm{T}$ score $=-1.4$ with $\mathrm{p}<0.001$ for both.

\section{Discussion}

Bone is a target organ for toxic metals as $\mathrm{Cd}$ and $\mathrm{Pb}$ with increased risk of fragility fractures Berglund et al. (2000). These metals were correlated with lower BMD and osteoporosis. Lead was found to be associated with reduced bone calcification (Jarup and Akesson, 2009). In the present study, osteoporotic patients, showed significantly increased
Table 2. The levels of blood $\mathrm{Cd}$ and $\mathrm{Pb}(\mathrm{ppb})$ in studied groups (mean $\pm \mathrm{SD}$ ).

\begin{tabular}{cccc}
\hline Metal & Osteoporosis & Control & p-value \\
\hline $\mathrm{Cd}(\mathrm{ppb})$ & $0.06 \pm 0.01$ & $0.02 \pm 0.001$ & $<0.001$ \\
$\mathrm{~Pb}(\mathrm{ppb})$ & $0.7 \pm 0.04$ & $0.3 \pm 0.03$ & $<0.001$
\end{tabular}

Data are presented as median (IQR), Significant difference $(\mathrm{p}<0.05)$. Cd: Cadmium; Pb: Lead.

blood levels of $\mathrm{Cd}$ and $\mathrm{Pb}$ as compared with control group (Delmas, 2008). The mechanism of association between toxic metals and fragility was attributed to renal tissue damage, which lead to decreased calcium reabsorption. Another explanation was also regarded for $\mathrm{Cd}$ due to it interfere with calcium reabsorption. In addition, vitamin $\mathrm{D}$ deficiency contributed in bone loss, decreased BMD and increased bone resorption to maintain blood calcium (Saltman and Strause, 1993). However, Pb, can replace the calcium content in hydroxyapatite and has a higher affinity for osteocalcin than calcium (Staessen et al., 1999; Akesson et al., 2006). The current study emphasized the association between $\mathrm{Cd}$ and $\mathrm{Pb}$ in the blood and the incidence of osteoporosis in Saudi population, which is consistent with previously reported studies of populations in Japan, Sweden and Belgium (Jin et al., 2004; Wang et al., 2003; Chen et al., 2011). In opposition with our findings, no association was reported between urinary cadmium and BMD in female Japanese farmers (Lv et al., 2017). This contradictory result could be explained by the valuable effects of exercise performed by the working women on bone, since physical exercise was consistently reported to enhance muscle strength and improve bone density (Schutte et al., 2008).

The increased level of osteocalcin in osteoprosis is attributed to decrease BMD and increased bone turnover. A high bone turnover can disrupt the trabecular architecture which reduces the bone strength in osteoporosis, ultimately resulting in decreased levels of bone mineral density.

Our data revealed that there is a link between blood lead and cadmium and the risk of osteoporosis. The mechanisms are complex. It is suggested that high cadmium levels decrease the formation of calcitriol (active Vitamin D) in blood, thereby decreasing calcium absorption; increasing 
Table 3. Uni-variant logistic regression.

\begin{tabular}{|c|c|c|c|c|c|c|c|c|c|}
\hline \multirow{2}{*}{ Variable } & \multirow{2}{*}{ B } & \multirow{2}{*}{ S.E. } & \multirow{2}{*}{ Wald } & \multirow{2}{*}{ df } & \multirow{2}{*}{ p-value } & \multirow{2}{*}{ OR } & \multicolumn{2}{|c|}{ 95\% CI } & \multirow{2}{*}{$\begin{array}{c}\text { Nagelkerke } \\
\text { R Square }\end{array}$} \\
\hline & & & & & & & Lower & Upper & \\
\hline Age & 0.080 & 0.025 & 10.405 & 1 & 0.001 & 1.083 & 1.032 & 1.137 & 0.269 \\
\hline BMI & 0.017 & 0.056 & 0.095 & 1 & 0.758 & 1.017 & 0.911 & 1.136 & 0.002 \\
\hline Calcium & -0.352 & 0.398 & 0.782 & 1 & 0.377 & 0.703 & 0.322 & 1.535 & 0.019 \\
\hline Vitamin D & -0.079 & 0.028 & 8.171 & 1 & 0.004 & 0.924 & 0.875 & 0.976 & 0.269 \\
\hline Osteocalcin & -0.98 & -0.87 & 6.12 & 1 & 0.001 & 1.032 & & & \\
\hline
\end{tabular}

B: Coefficient; S.E.: Standard Error; df: Degree of freedom; OR: Odd ratio; CI: Confidence Interval; BMI: Body mass index.

Table 4. Multi-variant logistic regression for age, BMI, Ca and vitamin D for blood Cd and Pb concentrations among osteoporosis group and control group.

\begin{tabular}{|c|c|c|c|c|c|c|c|c|c|}
\hline \multirow{2}{*}{ Variable } & \multirow{2}{*}{ B } & \multirow{2}{*}{ S.E. } & \multirow{2}{*}{ Wald } & \multirow{2}{*}{ df } & \multirow{2}{*}{ p-value } & \multirow{2}{*}{ OR } & \multicolumn{2}{|c|}{ 95\% CI } & \multirow{2}{*}{$\begin{array}{l}\text { Nagelkerke R } \\
\text { Square }\end{array}$} \\
\hline & & & & & & & Lower & Upper & \\
\hline Age & .104 & .034 & 9.413 & 1 & .002 & 1.110 & 1.038 & 1.186 & 0.504 \\
\hline BMI & -.017 & .076 & .049 & 1 & .825 & .983 & .846 & 1.142 & \\
\hline Calcium & -.546 & .448 & 1.489 & 1 & .222 & .579 & .241 & 1.393 & \\
\hline Vitamin D & -.090 & .032 & 7.999 & 1 & .005 & .914 & .859 & .973 & \\
\hline Osteocalcin & -0.991 & 0.632 & 9.32 & 1 & .001 & 1.914 & .739 & .912 & \\
\hline
\end{tabular}

B: Coefficient; S.E.: Standard Error; df: Degree of freedom; OR: Odd ratio; CI: Confidence Interval; BMI: Body mass index.

Table 5. Pearson's correlations coefficients and p-values between $\mathrm{Cd}$ and $\mathrm{Pb}$.

\begin{tabular}{cccc}
\hline Group & Metal & Correlations & $\mathbf{P b}$ \\
\hline Osteoporosis & $\mathrm{Cd}$ & $\mathrm{R}$ & 0.505 \\
& & $\mathrm{p}$ - value & 0.004 \\
& & $\mathrm{~N}$ & 30 \\
Control & $\mathrm{Cd}$ & $\mathrm{R}$ & -0.465 \\
& & $\mathrm{p}-$ value & 0.010 \\
& & $\mathrm{~N}$ & 30 \\
\hline
\end{tabular}

Cd: Cadmium; Pb: Lead; R: Pearson's correlation; N: Number of subjects.

bone resorption and break down the collagen matrix, inhibiting osteoblasts; and altering the expression of genes involved in bone homeostasis (Hsu et al., 2009). Cadmium can also induce reactive oxygen species production and oxidative stress (Kawakami et al., 2013), both the mentioned reasons can induce osteoporosis (Hsu et al., 2014). Also, lead is known for suppression of key genes for leptin and adiponectin, which are required to maintain healthy BMD.

\section{Conclusion}

We observed that in comparison to healthy subjects, osteoporotic patients have higher levels of lead and cadmium which are known to reduce bone mineral density and hence lead to osteoporosis.

\section{Acknowledgements}

This project was funded by the Deanship of Scientific Research (DSR), King Abdulaziz University, Jeddah, Saudi Arabia, under grant no. (KEP-PhD-47-130-38). The authors, therefore, acknowledge with thanks DSR for technical and financial support.

\section{References}

AKESSON, A., BJELLERUP, P., LUNDH, T., LIDFELDT, J., NERBRAND, C., SAMSIOE, G., SKERFVING, S. and VAHTER, M., 2006. Cadmiuminduced effects on bone in a population-based study of women. Environmental Health Perspectives, vol. 114, no. 6, pp. 830-834. http://dx.doi.org/10.1289/ehp.8763. PMid:16759980.

ARGÜELLES-VELÁZQUEZ, N., ALVAREZ-GONZÁLEZ, I., MADRIGALBUJAIDAR, E. and CHAMORRO-CEVALLOS, G., 2013. Amelioration of cadmium-produced teratogenicity and genotoxicity in mice given Arthrospira maxima (Spirulina) treatment. Evidence-Based Complementary and Alternative Medicine, vol. 2013, pp. 604535. http://dx.doi.org/10.1155/2013/604535. PMid:24369479.

BERGLUND, M., ÃKESSON, A., BJELLERUP, P. and VAHTER, M., 2000. Metal-bone interactions. Toxicology Letters, vol. 112-113, pp. 219-225. http://dx.doi.org/10.1016/S0378-4274(99)00272-6. PMid:10720734.

BOSCH, A.C., O'NEILL, B., SIGGE, G.O., KERWATH, S.E. and HOFFMAN, L.C., 2016. Heavy metals in marine fish meat and consumer health: a review. Journal of the Science of Food and Agriculture, vol. 96, no. 1, pp. 32-48. http://dx.doi.org/10.1002/jsfa.7360. PMid:26238481.

CASTELLI, M., ROSSI, B., CORSETTI, F., MANTOVANI, A., SPERA, G., LUBRANO, C., SILVESTRONI, L., PATRIARCA, M., CHIODO, F. and MENDITTO, A., 2005. Levels of cadmium and lead in blood: an application of validated methods in a group of patients 
with endocrine/metabolic disorders from the Rome area. Microchemical Journal, vol. 79, no. 1-2, pp. 349-355. http:// dx.doi.org/10.1016/j.microc.2004.05.003.

CHEN, X., ZHU, G., JIN, T., QIN, B., ZHOU, W. and GU, S., 2011. Cadmium is more toxic on volume bone mineral density than tissue bone mineral density. Biological Trace Element Research, vol. 144, no. 1-3, pp. 380-387. http://dx.doi.org/10.1007/s12011011-9106-x. PMid:21656269.

DELMAS, P.D., 2008. Clinical potential of RANKL inhibition for the management of postmenopausal osteoporosis and other metabolic bone diseases. Journal of Clinical Densitometry, vol. 11, no. 2, pp. 325-338. http://dx.doi.org/10.1016/j.jocd.2008.02.002. PMid:18375161.

DERMIENCE, M., LOGNAY, G., MATHIEU, F. and GOYENS, P., 2015. Effects of Thirty Elements on Bone Metabolism. Journal of Trace Elements in Medicine and Biology, vol. 32, pp. 86-106. http://dx.doi.org/10.1016/j.jtemb.2015.06.005. PMid:26302917.

GARTELL, M.J., CRAUN, J.C., PODREBARAC, D.S. and GUNDERSON, E.R., 1986. Pesticides, selected elements and other chemicals in infant and toddler total diet samples, October 1980-March 1982. Journal - Association of Official Analytical Chemists, vol. 69, no. 1, pp. 123-145. PMid:3949685.

HIGAZY, A., HASHEM, M., ELSHAFEI, A., SHAKER, N. and HADY, M.A., 2010. Development of anti-microbial jute fabrics via in situ formation of cellulose-tannic acid-metal ion complex. Carbohydrate Polymers, vol. 79, no. 4, pp. 890-897. http://dx.doi. org/10.1016/j.carbpol.2009.10.019.

HSU, C.W., LIN, J.L., LIN-TAN, D.T., HUANG, W.H., CHEN, K.H. and YEN, T.H., 2014. Association between blood cadmium levels and malnutrition in peritoneal dialysis. BMC Nephrology, vol. 15, no. 1, pp. 17. http://dx.doi.org/10.1186/1471-2369-15-17. PMid:24428882.

HSU, C.W., LIN, J.L., LIN-TAN, D.T., YEN, T.H., HUANG, W.H., HO, T.C. HUANG, Y.L., YEH, L.M. and HUANG, L.M., 2009. Association of environmental cadmium exposure with inflammation and malnutrition in maintenance haemodialysis patients. Nephrology, Dialysis, Transplantation, vol. 24, no. 4, pp. 1282 1288. http://dx.doi.org/10.1093/ndt/gfn602. PMid:19028751.

ISHAK, I., ROSLI, F.D., MOHAMED, J. and MOHD ISMAIL, M.F., 2015. Comparison of Digestion Methods for the Determination of Trace Elements and Heavy Metals in Human Hair and Nails. The Malaysian Journal of Medical Sciences: MJMS, vol. 22, no. 6, pp. 11-20. PMid:28223880.

JALILI, C., KAZEMI, M., TAHERI, E., MOHAMMADI, H., BOOZARI, B., HADI, A. and MORADI, S., 2020. Exposure to heavy metals and the risk of osteopenia or osteoporosis: a systematic review and meta-analysis. Osteoporosis International, vol. 31, no. 9, pp. 1671-1682. http://dx.doi.org/10.1007/s00198-020-05429-6. PMid:32361950.

JÄRUP, L. and AKESSON, A., 2009. Current status of cadmiumas an environmental health problem. Toxicology and Applied Pharmacology, vol. 238, no. 3, pp. 201-208. http://dx.doi. org/10.1016/j.taap.2009.04.020. PMid:19409405.

JIN, T., NORDBERG, G., YE, Y., BO, M., WANG, H., ZHU, G., KONG, Q. and BERNARD, A., 2004. Osteoporosis and renal dysfunction in a general population exposed to cadmium in China. Environmental Research, vol. 96, no. 3, pp. 353-359. http://dx.doi.org/10.1016/j. envres.2004.02.012. PMid:15364604.

KAWAKAMI, T., NISHIYAMA, K., KADOTA, Y., SATO, M., INOUE, M. and SUZUKI, S., 2013. Cadmium modulates adipocyte functions in metallothionein-null mice. Toxicology and Applied Pharmacology, vol. 272, no. 3, pp. 625-636. http://dx.doi. org/10.1016/j.taap.2013.07.015. PMid:23921151.

KLAASSEN, C.D., 2003. Casarett and Doull's essentials of toxicology: principles of toxicology. New York: McGraw-Hill, 6-20.
LAVADO-GARCÍA, J.M., PUERTO-PAREJO, L.M., RONCERO-MARTÍN, R., MORAN, J.M., PEDRERA-ZAMORANO, J.D., ALIAGA, I.J., LEALHERNÁNDEZ, O. and CANAL-MACIAS, M.L., 2017. Dietary intake of cadmium, lead and mercury and its association with bone health in healthy premenopausal women. International Journal of Environmental Research and Public Health, vol. 14, no. 12, pp. 1437. http://dx.doi.org/10.3390/ijerph14121437. PMid:29168740.

LV, Y., WANG, Y.P., HUANG, R., LIANG, X., WANG, P., TAN, J., CHEN, Z., DUN, Z., WANG, J., JIANG, Q., WU, S., LING, H., LI, Z. and YANG, X., 2017. Cadmium exposure and osteoporosis: a populationbased study and benchmark dose estimation in southern China. Journal of Bone and Mineral Research, vol. 32, no. 10, pp. 32. http://dx.doi.org/10.1002/jbmr.3151. PMid:28407309.

MACHOLZ, R.M., 1978. The biogeochemistry of lead in the environment, part A: ecological cycles. New York: Elsevier/North-Holland Biomedical Press.

MADEDDU, R., SOLINAS, G., FORTE, G., BOCCA, B., ASARA, Y., TOLU, P., DELOGU, L.G., MURESU, E., MONTELLA, A. and CASTIGLIA, P., 2011. Diet and Nutrients are Contributing Factors that Influence Blood Cadmium Levels. Nutrition Research, vol. 31, no. 9, pp. 691-697. http://dx.doi.org/10.1016/j.nutres.2011.09.003. PMid:22024493.

MOL, S., 2011. Levels of toxic metals in canned bonito, sardines, and mackerel produced in Turkey. Biological Trace Element Research, vol. 143, no. 2, pp. 974-982. http://dx.doi.org/10.1007/ s12011-010-8909-5. PMid:21120704.

PAPANIKOLAOU, N.C., HATZIDAKI, E.G., BELIVANIS, S., TZANAKAKIS, G.N. and TSATSAKIS, A.M., 2005. Lead toxicity update: a brief review. Medical Science Monitor, vol. 11, no. 10, pp. RA329RA336. PMid:16192916.

RAGAB, A.R., FAROUK, O., AFIFY, M.M., ATTIA, A.M., SAMANOUDY, A.E. and AND TAALAB, J.M., 2014. The role of oxidative stress in carcinogenesis induced by metals in breast cancer Egyptian females sample at Dakahlia Governorate. Journal of Environmental \& Analytical Toxicology, vol. 4, pp. 2.

SALTMAN, P.D. and STRAUSE, L.G., 1993. The role of trace minerals in osteoporosis. Journal of the American College of Nutrition, vol. 12, no. 4, pp. 384-389. http://dx.doi.org/10.1080/07315724.19 93.10718327. PMid:8409100.

SCHULZ, U.H. and MARTINS-JUNIOR, H., 2001. Astyanax fasciatus AS Bioindicator of water pollution of rio dos sinos, rs, brazil. Brazilian Journal of Biology = Revista Brasileira de Biologia, vol. 61, no. 4, pp. 615. http://dx.doi.org/10.1590/S1519-69842001000400010. PMid:12071317.

SCHUTTE, R., NAWROT, T.S., RICHART, T., THIJS, L., VANDERSCHUEREN, D., KUZNETSOVA, T., VAN HECKE, E., ROELS, H.A. and STAESSEN, J.A., 2008. Bone resorption and environmental exposure to cadmium in women: A population study. Environmental Health Perspectives, vol. 116, no. 6, pp. 777-783. http://dx.doi. org/10.1289/ehp.11167. PMid:18560534.

STAESSEN, J.A., ROELS, H.A., EMELIANOV, D., KUZNETSOVA, T., THIJS, J., VANGRONSVELD, J. and FAGARD, R., 1999. Environmental exposure to cadmium, forearm bone density, and risk of fractures: Prospective population study. Public Health and Environmental Exposure to Cadmium (PheeCad) Study Group. Lancet, vol. 353, no. 9159, pp. 1140-1144. http://dx.doi. org/10.1016/S0140-6736(98)09356-8. PMid:10209978.

WANG, H., ZHU, G., SHI, Y., WENG, S., JIN, T., KONG, Q. and NORDBERG, G.F., 2003. Influence of environmental cadmium exposure on forearm bone density. Journal of Bone and Mineral Research, vol. 18, no. 3, pp. 553-560. http://dx.doi.org/10.1359/ jbmr.2003.18.3.553. PMid:12619941. 